EXTENDED REPORT

\title{
Antiphospholipid syndrome associated with infections: clinical and microbiological characteristics of 100 patients
}

\author{
R Cervera, R A Asherson, M L Acevedo, J A Gómez-Puerta, G Espinosa, G de la Red, V Gil, \\ M Ramos-Casals, M García-Carrasco, M Ingelmo, J Font
}

Ann Rheum Dis 2004;63:1312-1317. doi: 10.1136/ard.2003.014175

See end of article for authors' affiliations

\section{Correspondence to:}

Dr R Cervera, Servei de Malalties Autoimmunes, Hospital Clínic, Villarroe 170, 08036-Barcelona,

Catalonia, Spain; rcervera@clinic.ub.es

Accepted

19 November 2003

\begin{abstract}
Objective: To describe and analyse the clinical characteristics of 100 patients with antiphospholipid syndrome (APS) associated with infections.

Methods: Patients were identified by a computer assisted search (Medline) of published reports to locate all cases of APS published in English, Spanish, and French from 1983 to 2003. The bilateral Fisher exact test was used for statistics.

Results: 59 female and 41 male patients were identified (mean (SD) age, 32 (18) years (range 1 to 78)): 68 had primary APS, 27 had systemic lupus erythematosus, two had "lupus-like" syndrome, two had inflammatory bowel disease, and one had rheumatoid arthritis. APS presented as a catastrophic syndrome in $40 \%$ of cases. The main clinical manifestations of APS included: pulmonary involvement $(39 \%)$, skin involvement (36\%), and renal involvement (35\%; nine with renal thrombotic microangiopathy, RTMA). The main associated infections and agents included skin infection (18\%), HIV (17\%), pneumonia (14\%), hepatitis C (13\%), and urinary tract infection (10\%). Anticoagulation was used in $74 \%$, steroids in $53 \%$, intravenous immunoglobulins in $20 \%$, cyclophosphamide in $12 \%$, plasma exchange in $12 \%$, and dialysis in $9.6 \%$. Twenty three patients died following infections and thrombotic episodes (16 with catastrophic APS). Patients given steroids had a better prognosis $(p=0.024)$. The presence of RTMA and requirement for dialysis carried a worse prognosis $(p=0.001$ and $p=0.035$, respectively).

Conclusions: Various different infections can be associated with thrombotic events in patients with APS, including the potentially lethal subset termed catastrophic APS. Aggressive treatment with anticoagulation, steroids, and appropriate antibiotic cover is necessary to improve the prognosis.
\end{abstract}

$\mathrm{T}$ he detection of antiphospholipid antibodies (aPL) - that is, lupus anticoagulant or anticardiolipin antibodies-is of interest because of their importance in the pathogenesis of clotting in the antiphospholipid syndrome (APS). APS occurs not only in systemic autoimmune diseases, particularly systemic lupus erythematosus (SLE), but also in patients who do not manifest overt symptoms of other autoimmune disturbances (primary APS), where the emphasis is primarily on vascular events. ${ }^{12}$

Since 1983, many infections have been found to be associated with aPL positivity, although a pathogenic role for these antibodies was not usually obvious except in a few isolated cases. Over recent years it has been emphasised and reported on several occasions ${ }^{3-5}$ that many infections may not only trigger the production of these antibodies but also appear be accompanied by clinical manifestations of the APS itself. This has been seen particularly in patients with catastrophic APS. ${ }^{6-8}$

In this study we made the first literature analysis-some 20 years after the definition of APS - of patients who developed an APS associated with, and probably triggered by, infections. In this series, comprising a total of 100 patients, we further clarify the importance of this association and discuss other clinical aspects, including treatment and prognosis.

\section{METHODS}

Patients were identified by a computer assisted search of published reports (Medline, National Library of Medicine, Bethesda, Maryland, USA) to locate all cases of APS published in English, Spanish, and French from 1983 (when APS was first defined) to 2003.
We also analysed several original cases that were categorised as having APS or as having aPL or lupus anticoagulant associated with any infection in which there was a thrombotic process. We scanned bibliographies of all articles for references not identified in the initial search. Only cases with well documented clinical summaries and relevant information were included in the review.

Data from these papers were summarised using a standardised data form, including sex, age, diagnosis of the underlying condition, associated infections, major thrombotic clinical manifestations, immunological features, treatment, and course. Two new cases of APS from our clinics, both associated with urinary infection, are added to the review as illustrative case reports (see the appendix).

The bilateral Fisher exact test was used for statistics.

\section{RESULTS}

In all, 100 patients with APS manifestations associated with infections were reviewed: 98 from the literature $\operatorname{search}^{6-56}$ plus two from our own clinics.

\section{General characteristics}

General clinical features of these patients are shown in table 1 . Fifty nine per cent were female and $41 \%$ male. Their mean (SD) age was 32 (18) years (range 1 to 78 ). There were 24 young patients (under 18 years), who were affected mainly by skin and respiratory infections. Sixty eight patients had primary APS, 27 had SLE, two had "lupus-like" disease, two had inflammatory bowel disease (one Crohn's disease

Abbreviations: aPL, antiphospholipid antibodies; APS, antiphospholipid syndrome; RTMA, renal thrombotic microangiopathy 
Table 1 General characteristics

\begin{tabular}{ll}
\hline & Per cent $(\mathbf{n}=100)$ \\
\hline Female & 59 \\
Male & 41 \\
SLE & 27 \\
Primary APS & 68 \\
Catastrophic APS & 40 \\
Lupus-like & 2 \\
Rheumatoid arthritis & 1 \\
IBS & 2 \\
\hline \multirow{2}{*}{ APS, antiphospholipid syndrome; IBS, inflammatory bowel } \\
disease.
\end{tabular}

and one ulcerative colitis), and one had rheumatoid arthritis. In 40 of the 100 cases, the thrombotic events appeared in the form of catastrophic APS.

\section{Clinical presentation}

Pulmonary involvement was present in 39 patients: in 24 as adult respiratory distress syndrome (ARDS), in 18 as pulmonary embolism, in three as pulmonary haemorrhage, and in one as pulmonary hypertension. Skin involvement was reported in 36 patients: 16 had livedo reticularis, nine had purpura fulminans, eight had skin ulcers, and three had digital necrosis. Renal involvement was reported in 35 patients, nine of whom had renal thrombotic microangiopathy (RTMA). Almost one third of the patients (31\%) had cerebral disease, manifested as cerebrovascular accidents (CVA) in 21 patients, encephalopathy in seven, and other cerebral features in seven, including seizures, psychosis, or cerebral microinfarcts. Peripheral thrombosis was reported in 30 patients ( 15 had deep vein thrombosis). Other types of vascular thrombosis were: femoral artery occlusions in nine patients, vena cava thrombosis in four, radial artery thrombosis in one, and thrombosis of other arteries in three. Cardiac disease was found in 24 patients, presenting as myocardial infarction in 12, valve lesions in 10, and cardiac microthrombi in one; other cardiac features were reported in five (cardiogenic shock and atrial thrombus). Ten patients had avascular necrosis of the hip joint, in all cases accompanied by HIV infection. In only one case was the previous use of steroids reported (given for thrombocytopenia). We excluded all cases with other possible causes of avascular necrosis, including high triglyceride levels or protease inhibitor use. The remaining APS manifestation are summarised in table 2 .

\section{Associated infections}

The associated infections and microbiological agents are shown in table 3. Skin infection (18\%), human immunodeficiency virus (HIV) infection (17\%), pneumonia (14\%), hepatitis C virus (HCV) infection (13\%), and urinary infection (10\%) were the commonest associated infections. In nine cases, more than one organ or agent was identified as a source of infection. Other infections less frequently associated with APS were identified, including mycoplasma (3), cytomegalovirus (CMV) (3), fungal infections (2), pulmonary tuberculosis (2), malaria (2), P carinii (1), and leptospirosis (1).

\section{Treatment}

Most of the patients received the appropriate antibiotic and antiviral treatment according to the underlying infection. In five cases, this was given as sole treatment. The treatment was not reported in 17 cases. Table 4 shows the differing types of treatment used. Anticoagulation was the most common, used in 61 of 83 patients $(73 \%)$. Steroids were used in 43 patients (53\%), intravenous immunoglobulins in $17(20 \%)$, cyclophosphamide in $10(12 \%)$, and plasma exchange in $10(12 \%)$. Aspirin was used in six patients $(7 \%)$, dialysis in eight $(10 \%)$, fibrinolytics in six $(7 \%)$, and fresh frozen plasma in five $(6 \%)$. Different types of surgical procedures were undertaken, including arthroplasty in three $(4 \%)$, leg amputation in two $(2 \%)$, and vena cava filter, aortic repair, or splenectomy in one case $(1 \%)$ each.

\section{Outcome}

Twenty three patients died following infection and thrombotic episodes (in 16 cases with catastrophic APS). Other causes of death were related to RTMA (four cases), purpura fulminans (one case), CVA in a patient with varicella pneumonia, and HIV infection in one patient. Patients who received steroids had a better prognosis than the rest $(p=0.024)$. The presence of RTMA and need for dialysis carried a worse prognosis $(p=0.001$ and $p=0.035$, respectively). The remaining 77 patients recovered after the thrombotic event.

\begin{tabular}{|c|c|}
\hline & Per cent $(n=100)$ \\
\hline Pulmonary & 39 \\
\hline ARDS & 24 \\
\hline Pulmonary embolism & 18 \\
\hline Pulmonary haemorrhage & 3 \\
\hline Pulmonary hypertension & 1 \\
\hline Skin & 36 \\
\hline Livedo reticularis & 16 \\
\hline Purpura fulminans & 9 \\
\hline Skin ulcers & 8 \\
\hline Digital necrosis & 3 \\
\hline Renal & 35 \\
\hline RTMA & 9 \\
\hline Cerebral & 31 \\
\hline CVA & 21 \\
\hline Encephalopathy & 7 \\
\hline Other cerebral & 7 \\
\hline Peripheral thrombosis & 30 \\
\hline DVT & 15 \\
\hline Femoral artery & 9 \\
\hline Caval thrombosis & 4 \\
\hline Radial artery & 1 \\
\hline Other arteries & 3 \\
\hline Cardiac & 24 \\
\hline Myocardial infarction & 12 \\
\hline Válve lesion & 10 \\
\hline Cardiac microthrombi & 1 \\
\hline Other cardiac & 5 \\
\hline \multicolumn{2}{|l|}{ Intra-abdominal } \\
\hline Hepatic & 12 \\
\hline Splenic & 8 \\
\hline Neuropathy & 7 \\
\hline Intestinal & 6 \\
\hline Mesenteric & 5 \\
\hline Portal & 4 \\
\hline Pancreas & 3 \\
\hline \multicolumn{2}{|l|}{ Others } \\
\hline Avascular necrosis & 10 \\
\hline Genital & 2 \\
\hline Amaurosis fugax & 2 \\
\hline Other manifestations & 6 \\
\hline
\end{tabular}


Table 3 Associated infections

\begin{tabular}{ll}
\hline Agent or type & Per cent $(\mathbf{n}=100)^{*}$ \\
\hline Skin & 18 \\
HIV & 17 \\
VZV & 15 \\
Pneumonia & 14 \\
HCV & 13 \\
Urinary & 10 \\
Upper respiratory & 9 \\
Sepsis & 6 \\
Gastrointestinal & 6 \\
Staphylococci & 4 \\
Steptococci & 4 \\
E coli & 4 \\
Other Gram negative & 3 \\
Mycoplasmas & 3 \\
CMV & 3 \\
Malaria & 2 \\
Fungal & 2 \\
Tuberculosis & 2 \\
P carinii & 1 \\
Amoebiasis & 1 \\
Other viruses & 3 \\
Other infections & 6 \\
\hline & \\
*Note: in some patients more of one infection occurred. \\
CMV, cytomegalovirus; HIV, human immunodeficiency virus; \\
HCV, hepatitis C virus; VZV, varicella-zoster virus. \\
\hline
\end{tabular}

\section{DISCUSSION}

aPL were originally detected in human serum by Wasserman $^{57}$ almost 100 years ago, when his complement fixation test was first used for the diagnosis of syphilis, and when the Venereal Disease Research Laboratory (VDRL) test was described. ${ }^{58}$ A phospholipid termed cardiolipin was the major tissue extract used in this test. It was subsequently found that the VDRL was not specific for syphilis but was also positive in autoimmune diseases such as SLE. In 1983, cardiolipin was used for the first time as the antigen in a solid phase aPL specific assay by Harris et al, ${ }^{59}$ and the term APS was born. ${ }^{60}$ Syphilis was thus the first infection to be recognised as being linked to aPL. Since 1983, many other infections have been found to be associated with the presence of aPL, although a pathogenic role for these antibodies was not usually obvious except in a few isolated cases.

In 1990, it was found that the binding of the aPL to phospholipid was enhanced in autoimmune conditions by a "cofactor" known as $\beta_{2}$ glycoprotein I ( $\beta_{2}$ GPI) - a glycoprotein with anticoagulant properties-whereas the "non"thrombogenic aPL did not require this cofactor to enhance binding. The two types of aPL were referred to as "autoimmune" and "infectious" types. ${ }^{61-64}$ This distinction, however, was subsequently found not to be absolute, ${ }^{65-68}$ and it was postulated that infections may be a trigger factor for

Table 4 Treatment given in 83 cases*

\begin{tabular}{lll}
\hline & $\mathbf{n}$ & $\%$ \\
\hline Anticoagulation & 61 & 74 \\
Steroids & 44 & 53 \\
Immunoglobulins & 17 & 20 \\
Cyclophosphamide & 10 & 12 \\
Plasma exchange & 10 & 12 \\
Dialysis & 8 & 10 \\
Aspirin & 6 & 7 \\
Fibrinolytics & 6 & 7 \\
Fresh frozen plasma & 5 & 6 \\
Arthroplasty & 3 & 4 \\
Cyclosporin & 2 & 2 \\
Splenectomy & 1 & 1 \\
Other treatments & 7 & 8 \\
\hline \multirow{2}{*}{ *Treatment not specified in 17 cases. }
\end{tabular}

the induction of pathogenic aPL in certain predisposed individuals. In the present study, we have analysed the clinical and microbiological characteristics of 100 patients in whom pathogenic or thrombogenic aPL appeared in the course of an infectious process.

Microbial agents or viruses may induce autoimmune disease by several mechanisms. Although the specific factors resulting in the induction of aPL and the associated thrombotic events are still unknown, "molecular mimicry" and various infectious agents acting as superantigens have been proposed as mechanisms. Antigenic similarity between infectious agents and host tissues might result in a immune response to the shared determinant, resulting in disease. Polyclonal activation by the proteins of some infectious agents may act on particular subsets of the lymphocyte population-for example, viruses may destroy a particular $\mathrm{T}$ cell subset, upregulate Thl cytokines, selectively activate other $\mathrm{T}$ cell subsets, and directly stimulate cytokine and chemokine release, which may influence the expression of MHC class I and class II molecules. ${ }^{69-71}$ A hexapeptide (TLRVYK) has been identified by Blank et al. ${ }^{72}$ This is specifically recognised by a pathogenic anti- $\beta_{2}$ GPI monoclonal antibody. An evaluation of the pathogenic potential of a variety of microbial pathogens carrying sequences related to this hexapeptide in mice was carried out by the same group by infusing IgG specific to the peptide intravenously into naive mice. High titres of antipeptide anti- $\beta_{2}$ GPI antibodies were observed in mice immunised with $H$ influenzae, $N$ gonorrhoea, and tetanus toxoid. Significant thrombocytopenia, prolonged activated partial thromboplastin times, and increased percentages of fetal loss were also observed. ${ }^{72}$ Zhang et al recently identified an $S$ aureus protein (Sbi) which also bound $\beta_{2}$ GPI and could serve as a target molecule for IgG binding. ${ }^{73}$ Gharavi et al showed that synthetic peptides which share both structural similarity with the putative phospholipid binding region of the $\beta_{2}$ GPI molecule and a high homology with CMV were able to induce aPL in $\mathrm{NIH} /$ Swiss mice. ${ }^{74} 75$

Many viral infections may be accompanied by increases in aPL. ${ }^{76-88}$ Among these, HCV $^{76-81}$ and HIV ${ }^{85-88}$ infections have been intensively studied. In 1986, Bloom et al first documented lupus anticoagulant in $44 \%$ of AIDS patients and in $43 \%$ of asymptomatic HIV positive individuals (in which they may be transient). ${ }^{85}$ The anticardiolipin antibodies described in HIV patients are of both the pathogenic ( $\beta_{2}$ GPI cofactor dependent) and the infectious type ( $\beta_{2}$ GPI independent). ${ }^{86-88}$ As HIV infection leads to immunosuppression affecting mainly CD4+ cells and macrophages, it is possible that the pathophysiological mechanism of APS associated with HIV is different from that in other infections.

Many bacterial infections are associated with aPL. However, the increase is not usually associated with thrombotic events. Of interest, however, is the fact thatalthough $\beta_{2}$ GPI dependence is usually not present in this group-in patients with leprosy (particularly in the multibacillary type of leprosy) the anticardiolipin antibodies may be $\beta_{2}$ GPI dependent, as is found in autoimmune diseases. ${ }^{89}$ Lucio's phenomenon is a rare manifestation of leprosy in which the histopathological findings are related to microvascular thromboses in the absence of inflammatory infiltration of the vessel walls. Levy et al showed that this type of leprosy was associated with $\beta_{2}$ GPI dependency of the anticardiolipin antibodies. ${ }^{90}$ One patient has been documenteda young adult who developed an APS in childhood following a pulmonary infection with $M$ pneumoniae. ${ }^{91}$ Streptococcal infections may also be associated with raised titres of anticardiolipin antibodies. There has been controversy over rheumatic heart disease, with some investigators reporting raised titres and others not confirming these findings. 
Q fever, caused by Coxiella burnetti, is also associated with a high frequency of anticardiolipin antibody positivity.

Of particular interest is the unusual but potentially fatal subset of catastrophic APS. ${ }^{92}$ Until now, more than 200 such patients have been collected in an international registry. ${ }^{52}$ 93-95 Forty patients from the present series (40\%) developed catastrophic APS after infectious episodes. Several triggering factors became apparent when these cases were analysed. These included trauma, withdrawal of anticoagulation, and carcinoma, but particularly infections. ${ }^{93}$ The latest published analysis ${ }^{6}$ has shown that no less than $24 \%$ of catastrophic APS cases were preceded by infections. These comprised respiratory $(10 \%)$, cutaneous, including infected leg ulcers $(4 \%)$, urinary tract $(4 \%)$, gastrointestinal $(2 \%)$, general sepsis $(1 \%)$, and other infections (3\%). Molecular mimicry has also recently been proposed for the development of catastrophic APS following infections. ${ }^{96}$

Regarding treatment, in the present study we found that a wide variety of treatments had been given. Most patients received anticoagulants (74\%) plus immunosuppressive or immunomodulatory treatment. Patients who received steroids had a better prognosis than those who did not. Recently, Annane et al showed that the use of steroids reduced the risk of death in patients with septic shock and relative adrenal insufficiency. ${ }^{97}$ Furthermore, guidelines for the treatment of patients with catastrophic APS have recently been published ${ }^{95}$ and include the prompt use of antibiotic cover if infection is suspected.

\section{Conclusions}

A wide variety of infections can be associated with thrombotic events in patients with APS, including the potentially lethal subset termed catastrophic APS. A disproportionately large number of patients develop catastrophic APS following infection, bearing in mind the small number of catastrophic cases documented in published reports (around 200) as opposed to the several thousand with simple/classic APS. This emphasises a major difference in the pathogenesis between the two conditions that remains to be explored in future studies, and also the need for early diagnosis and aggressive antibiotic treatment as soon as infection is suspected in a patient with APS.

\section{Authors' affiliations \\ R Cervera, M L Acevedo, J A Gómez-Puerta, G Espinosa, G de la Red, V Gil, M Ramos-Casals, M García-Carrasco, M Ingelmo, J Font, Department of Autoimmune Diseases, Hospital Clinic, Barcelona, Catalonia, Spain \\ R A Asherson, Rheumatic Diseases Unit, Department of Medicine, University of Cape Town School of Medicine and Groote Schuur Hospital, Cape Town, South Africa}

\section{APPENDIX}

\section{CASE 1}

A 42 year old white women was diagnosed with SLE 25 years ago. Over the following years she had several exacerbations of articular involvement, with progressive hand deformity (Jaccoud arthropathy) and oral ulcers that resolved with small doses of corticosteroids and non-steroidal anti-inflammatory drugs. In 1992, Libman-Sacks endocarditis and livedo reticularis were detected and laboratory tests showed the presence of lupus anticoagulant. She began treatment with acenocumarol. Six months later, she was admitted because of a urinary tract infection. Urine cultures were positive for $E$ coli. She was treated with ciprofloxacin and discharged in good condition. The day after discharge, she developed epigastric pain accompanied by nausea, vomiting, diarrhoea, and fever $\left(39^{\circ} \mathrm{C}\right)$. She had livedo reticularis and lower limb oedema and complained of upper abdominal pain (with normal peristalsis) and occasional chest discomfort. A systolic murmur was detected in the mitral valve area.

Laboratory tests revealed a marked rise in transaminases (aspartate transaminase $1313 \mathrm{I} / \mathrm{U}$, alanine transaminase 1530 $\mathrm{I} / \mathrm{U})$, alkaline phosphatase (353 I/U), and lactic dehydrogenase $(3735 \mathrm{I} / \mathrm{U})$. The platelet count was $88 \times 10^{9} / \mathrm{l}$, haemoglobin $8.8 \mathrm{~g} / \mathrm{l}$, packed cell volume $26 \%$, white blood count (WBC) $7 \times 10^{9} / \mathrm{l}$, and creatinine $1.9 \mathrm{mg} / \mathrm{dl}$. Direct and indirect Coombs tests were positive. Peripheral blood smears showed no evidence of schistocytes. The erythrocyte sedimentation rate (ESR) was $93 \mathrm{~mm} / \mathrm{h}$, anti-ds-DNA was positive; complement levels were low $(\mathrm{C} 3=0.117, \mathrm{C} 4<0.07$, and $\mathrm{CH} 50$ activity $=7$ ); 24 hour urinary protein excretion was $538 \mathrm{mg}$. IgG anticardiolipin antibodies and lupus anticoagulant were positive, with negative IgM anticardiolipin antibodies. An ECG revealed ST segment and $\mathrm{T}$ wave abnormalities. Echocardiography showed mitral insufficiency and a valvar vegetation. Left ventricular size and function appeared normal. There was an inferior hypokinesia. There was enzymatic evidence of a myocardial infarct (creatinine phosphokinase MB isoenzyme, $151 \mathrm{I} / \mathrm{U}$; troponin I, 132 $\mathrm{I} / \mathrm{U})$. Coronary angiography showed $100 \%$ occlusion of the proximal right coronary artery.

A stent was inserted with good results. She started treatment with clopidogrel, aspirin, heparin, and $\beta$ blockers. She was also treated with intravenous "pulse" methylprednisolone for the haemolytic anaemia, without improvement. Her platelet count fell to $35 \times 10^{9} /$. Intravenous immunoglobulin treatment was started. Her clinical course then stabilised and a gradual improvement occurred. She was diagnosed as having catastrophic APS with renal, cardiac, and hepatic involvement associated with a urinary infection by E Coli.

\section{CASE 2}

The patient was a 78 year old women with an eight year history of seizures treated with oral carbamazepine. She presented with chest pain and generalised soft tissue oedema of her lower right limb. Physical examination was unremarkable except for leg pain and oedema. Laboratory investigations showed an ESR of $14 \mathrm{~mm} / \mathrm{h}$, packed cell volume $39 \%$, haemoglobin $12.7 \mathrm{~g} / \mathrm{l}$, WBC $7480 \times 10^{9} / \mathrm{l}$, platelet count $155 \times 10^{9} / \mathrm{l}$, creatinine $0.8 \mathrm{mg} / \mathrm{dl}$, anti ds-DNA negative, and antinuclear antibodies (ANA) 1/40. Urinalysis showed the presence of white cells and culture for $E$ coli was positive. Ciprofloxacin treatment was given. External iliac vein and femoral thrombosis was diagnosed by the Doppler technique. Pulmonary scintigraphy showed a perfusion mismatch with a high probability of pulmonary embolism. She was diagnosed as having deep vein thromboses and pulmonary embolism. The thrombophilia tests showed positive lupus anticoagulant with negative anticardiolipin antibodies.

She began anticoagulation with heparin and acenocumarol. During the admission, she suddenly developed epileptic seizures. Computed tomography of the brain revealed lacunar infarcts. A diagnosis of primary APS associated with a urinary infection by $E$ coli was made.

\section{REFERENCES}

1 Asherson RA. A "primary" antiphospholipid syndrome. J Rheumatol 1988; 15:1742-4.

2 Asherson RA, Khamashta MA, Ordi-Ros J, et al. The "primary" antiphospholipid syndrome: major clinical and serological features. Medicine (Baltimore) 1989;68:366-76.

3 Shoenfeld Y, Blank M, Krause I. The relationship of antiphospholipid antibodies to infections - do they bind to infecting agents or may they even be induced by them? Clin Exp Rheumatol 2000;18:431-2.

4 Uthman IW, Gharavi AE. Viral infections and antiphospholipid antibodies. Semin Arthritis Rheum 2002;31:256-63.

5 Dalekos GN, Zachou K, Liaskos C. The antiphospholipid syndrome and infection. Curr Rheumatol Rep 2001;3:277-85. 
6 Asherson RA, Cervera R, Piette JC, Shoenfeld Y, Espinosa G, Petri MA, et al. Catastrophic antiphospholipid syndrome: clues to the pathogenesis from a series of 80 patients. Medicine (Baltimore) 2001;80:355-77.

7 Hayem G, Kassis N, Nicaise P, Bouvet P, Andremont A, Labarre C, et al. Systemic lupus erythematosus associated with catastrophic antiphospholipid syndrome occurring after typhoid fever. A possible role of Salmonella lipopolysaccharide in the occurrence of diffuse vasculopathy-coagulopathy. Arthritis Rheum 1999:42:1056-61.

8 Grinberg AR, Heller PG, Correa G, Sarano JF, Molinas FC, Nicastro MA, et al. Sindrome antifosfolipido catastrófico: comunicación de dos formas de presentación. Medicina (Buenos Aires) 1999;59:743-6.

9 Rojas-Rodríguez J, García-Carrasco M, Ramos-Casals M, EnriquezCoronel G, Colchero C, Cervera R, et al. Catastrophic antiphospholipid syndrome: clinical description and triggering factors in 8 patients. J Rheumatol 2000;27:238-40.

10 Scully RE, Mark EJ, McNelly W, NcNelly BU. Case records of the Massachusetts General Hospital. N Engl J Med 1990;322:754-69.

11 Abinader A, Hanly AJ, Lozada CJ. Catastrophic antiphospholipid syndrome associated with anti-beta-2-glycoprotein I lgA. Rheumatology 1999;38:84-5.

12 Maddison PJ, Thorpe C, Seale JRC, Ahmed W, Whiteley GS. Grand rounds from international lupus centres: "catastrophic" antiphospholipid syndrome. Lupus 2000;9:484-8.

13 Amital H, Levy Y, Davidson C, Lundberg I, Hariu A, Kosach Y, et al. Catastrophic antiphospholipid syndrome: remission following leg amputation in 2 cases. Semin Arthritis Rheum 2001;31:127-32.

14 Undas A, Swadzba J, Undas R, Musial J. Three episodes of acute multiorgan failure in a woman with secondary antiphospholipid syndrome. Pol Arch Med Wewn 1998;100:556-60.

15 Jou IM, Liu MF, Chao SC. Widespread cutaneous necrosis associated with antiphospholipid syndrome. Clin Rheumatol 1996;15:394-8.

16 Cisternas M, Gutierrez MA, Rosenberg H, Jara A, Jacobelli S. Catastrophic antiphospholipid syndrome associated with crescentic glomerulonephritis: a clinicopathologic case. Clin Exp Rheumatol 2000;18:252-4.

17 Scully RE, Mark EJ, McNeely WF, Ebeling SH, Ellender SM. Case records of the Massachusetts General Hospital. N Engl J Med 1999;340:1900-8.

18 Falcini F, Taccetti G, Ermini M, Trapani S, Cerinic MM. Catastrophic antiphospholipid antibody syndrome in pediatric systemic lupus erythematosus. J Rheumatol 1997;24:389-92.

19 Greisman SG, Thayaparan RS, Godwin TA, Lockshin MD. Occlusive vasculopathy in systemic lupus erythematosus. Association with anticardiolipin antibody. Arch Intern Med 1991;151:389-92.

20 Reitblat T, Drogenikov T, Sigalov I, Oren S, London D. Transient anticardiolipin antibody syndrome in a patient with parvovirus B19 infection. Am J Med 2000;109:512-13.

21 Suarez S, Artiles J, Balda I, Melado P, Arkuch ME, Ayala A, et al. La tuberculosis como factor de riesgo de trombosis venosa. An Med Inter (Madrid) 1993;10:398-400

22 Labarca JA, Rabaggliati RM, Radrigan FJ, Rojas PP, Perez CM, Ferres MV, et al. Antiphospholipid syndrome associated with cytomegalovirus infection: case report and review. Clin Infect Dis 1997:24:197-200.

23 Cappell MS, Simon T, Tiku M. Splenic infarction associated with anticardiolipin antibodies with acquired immunodeficiency syndrome. Dig Dis Sci 1993;38:1153-5.

24 Manco-Johnson MJ, Nuss R, Key N, Moertel C, Jacobson L, Meech S, et al. Lupus anticoagulant and protein $S$ deficiency in children with postvaricella purpura fulminans or thrombosis. J Pediatr 1996;128:319-23.

25 Peyton BD, Cutler BS, Stewart FM. Spontaneous tibial artery thrombosis associated with varicella pneumonia and free protein $S$ deficiency. J Vasc Surg 1998:27:563-7.

26 Puri V, Bookman A, Yeo E, Cameron R, Heathcote EJ. Antiphospholipid antibody syndrome associated with hepatitis $C$ infection. I Rheumatol 1999;26:509-10.

27 Uthman I, Tabbarah Z, Gharavi AE. Hughes syndrome associated with cytomegalovirus infection. Lupus 1999:8:775-7.

28 Viseux V, Darnige L, Carmi E, Chaby G, Poulain JF, Cevallos R, et al. Pulmonary embolism and transitory anti-beta2-GPI antibodies in an adult with chicken pox. Lupus 2000;9:558-60.

29 Leder AN, Flansbaum B, Zandman-Goddard G, Asherson R, Shoenfeld Y. Antiphospholipid syndrome induced by HIV. Lupus 2001;10:370-4.

30 Uthman T, Taher A, Khalil I. Hughes syndrome associated with varicella infection. Rheumatol Int 2001;20:167-8.

31 Creamer D, Hunt BJ, Black MM. Widespread cutaneous necrosis occurring in association with the antiphospholipid syndrome: a report of two cases. Br J Dermatol 2000;142:1199-203.

32 Baid S, Pascual M, Williams WW, Tolkoff-Rubin N, Johnson SM, Collins B, et al. Renal thrombotic microangiopathy associated with anticardiolipin antibodies in hepatitis C-positive renal allograft recipients. J Am Soc Nephrol 1999;10:146-53.

33 Casanova-Roman M, Rios J, Sanchez-Porto A, Casanova-Bellido M. Deep venous thrombosis associated with pulmonary tuberculosis and transient protein S deficiency. Scand J Infect Dis 2002;34:393-4.

34 Prieto J, Yuste JR, Beloqui O, Civeira MP, Riezu Jl, Aguirre B, et al. Anticardiolipin antibodies in chronic hepatitis C: implication of hepatitis C virus as the cause of the antiphospholipid syndrome. Hepatology 1996;23:199-204.

35 D'Angelo A, Della Valle P, Crippa L, Pattarini E, Grimaldi LM, Vigano D'Angelo $S$. Brief report: autoimmune protein $S$ deficiency in a boy with severe thromboembolic disease. N Engl J Med 1993;328:1753-7.

36 Levin M, Eley BS, Louis J, Cohen H, Young L, Heyderman RS. Postinfectious purpura fulminans caused by an autoantibody directed against protein $S$. J Pediatr 1995;127:355-63.
37 Becker DM, Saunders TJ, Wispelway B, Schain DC. Case report: venous thromboembolism in AIDS. Am J Med Sci 1992;303:395-7.

38 Chevalier X, Larget-Piet B, Hernigou P, Gherardi R. Avascular necrosis of the femoral head in HIV-infected patients. J Bone Joint Surg Br 1993;75B:160.

39 Belmonte MA, Garcia-Portales R, Domenech I, Fernandez-Nebro A, Camps MT, De Ramon E. Avascular necrosis of bone in human immunodeficiency virus infection and antiphospholipid antibodies. $J$ Rheumatol 1993;20:1424-8.

40 Malnick SD, Abend Y, Evron E, Sthoeger ZM. HCV hepatitis associated with anticardiolipin antibody and a cerebrovascular accident. Response to interferon therapy. J Clin Gastroenterol 1997;24:40-2.

41 Gibson GE, Gibson LE, Drage LA, Garrett CR, Gertz MA. Skin necrosis secondary to low-molecular weight heparin in a patient with antiphospholipid antibody syndrome. J Am Acad Dermatol 1997:37:855-9.

42 Olive A, Queralt C, Sierra G, Centelles M, Force L. Osteonecrosis and HIV infection: Osteonecrosis and HIV infection. I Rheumatol 1998;25:1243-4.

43 Cailleux N, Marie I, Jeanton M, Lecomte F, Levesque H, Courtois H. Are antiphospholipid antibodies pathogenic in the course of human immunodeficiency virus infection? J Mal Vasc 1999;24:53-6.

44 Yañez A, Cedillo L, Neyrolles O, Alonso E, Alonso E, Prevost MC, Rojas J, et al. Mycoplasma penetrans bacteremia and primary antiphospholipid syndrome. Emerg Infect Dis 1999:5:164-7.

45 Padovan CS, Pfister HW, Bense S, Fingerle V, Abele-Horn M. Detection of Mycoplasma pneumoniae DNA in cerebrospinal fluid of a patient with $M$. pneumoniae infection-"associated" stroke. Clin Infect Dis 2001;33:E1 19-21.

46 Korkmaz C, Harmanci E, Metintas I, Gulbas Z. Antiphospholipid syndrome associated with intestinal amoebiasis. Scand J Infect Dis 2001:33:938-40.

47 Nakajima T, Kitahara H, Kono T, Ohta K, Takano T, Hasegasa R, et al. A surgical case of acute aortic dissection with antiphospholipid syndrome. Jpn J Cardiovasc Surg 2001;30:311-13.

48 Turhal NS, Peters VB, Rand JH. Antiphospholipid syndrome in HIV infection report on four cases and review of the literature. ACl Internat $2001 ; 13: 268-71$

49 Brown P, Crane L. Avascular necrosis of bone in patients with human immunodeficiency virus infection: report of 6 cases and review of the literature. Clin Infect Dis 2001:32:1221-6.

50 Ehrenfeld M, Bar-Natan M, Sidi Y, Schwartz E. Antiphospholipid antibodies associated with severe malaria infection [abstract]. Lupus 2002;11:S611.

51 Roldan R, Perez-Guijo V, Anton M, Castro C, Collantes E. Two new cases of catastrophic APS in pediatric patients [abstract]. Lupus 2002;11:S618.

52 Cervera R, Gómez-Puerta JA, Espinosa G, Font J, De Pa Red G, Gil V, et al. "CAPS Registry": a review of 200 cases from the International Registry of patients with catastrophic antiphospholipid syndrome (CAPS) [abstract]. Ann Rheum Dis 2003;62(suppl 1):88.

53 Olguin-Ortega L, Jara L, Becerra M, Ariza R, Espinoza L, Wilson W, et al. Neurological involvement as a poor prognostic factor in catastrophic antiphospholipid syndrome: autopsy findings in 12 cases. Lupus 2003;12:93-8

54 Koschmieder S, Miesbach W, Fauth F, Bojunga J, Scharrer I, Brodt HR. Combined plasmapheresis and immunosuppression as a rescue treatment of a patient with catastrophic antiphospholipid syndrome. Blood Coagul Fibrinolysis 2003;14:395-9

55 Villamil A, Sorkin E, Basta MC, Mysler E, Macias S, Pekolj J, et al. Catastrophic antiphospholipid syndrome complicating orthotopic liver transplantation. Lupus 2003;12:140-3.

56 Tattevin P, Dupeux S, Hoff J. Leptospirosis and the antiphospholipid syndrome. Am J Med 2003;114:164.

57 Wasserman A. Uber Entwicklung und den Gegenwartingen Stand der Serodiagnostic Gegenuber Syphilis. Berl Klin Wochenschr 1907:44:1599-634

58 Michaelis L. Precipitin reaction bei syphilis. Berl KlinWochenschr 1907;44.

59 Harris EN, Gharavi AE, Boey ML, Patel BM, Mackworth-Young CG, Loizou S, et al. Anticardiolipin antibodies: detection by radioimmunoassay and association with thrombosis in systemic lupus erythematosus. Lancet 1983;ii: 1211-14

60 Harris EN, Baguley E, Asherson RA, Hughes GRVH. Clinical and serological features of the "antiphospholipid syndrome" [abstract]. Br J Rheumatol 1987;26:19

61 Galli M, Comfurius P, Maassen C, Hemker HC, de Baets MH, van BredaVriesman PJ, et al. Anticardiolipin antibodies (ACA) directed not to cardiolipin but to a plasma protein cofactor. Lancet 1990;335:1544-7.

62 McNeil HP, Simpson RJ, Chesterman CN, Krilis SA. Anti-phospholipid antibodies are directed against a complex antigen that includes a lipidbinding inhibitor of coagulation, $\beta 2$-glycoprotein 1 (apolipoprotein H). Proc Natl Acad Sci USA 1990;87:4120-4

63 Matsuura E, Igarashi Y, Fujimoto M, Ichikawa K, Koike T. Anticardiolipin cofactor(s) and differential diagnosis of autoimmune disease [lefter]. Lancet 1990:336:177-8.

64 Hunt JE, McNeil HP, Morgan GJ, Cramer IR, Krilis SA. A phospholipid B-B2glycoprotein I complex is an antigen for anticardiolipin antibodies occurring in autoimmune disease but not with infection. Lupus 1992;1:75-81.

65 Elbeialy A, Strassburger-Lorna K, Atsumi T, Bertolaccini ML, Amengual O, Hanafi $M$, et al. Antiphospholipid antibodies in leprotic patients: a correlation with disease manifestations. Clin Exp Rheumatol 2000;18:492-4.

66 Hojnik M, Gilburd B, Ziporen L, Blank M, Tomer Y, Scheinberg MA, et al. Anticardiolipin antibodies are heterogeneous in their dependency on B2glycoporotein 1: analysis of anticardiolipin antibodies in leprosy. Lupus 1994;3:515-21.

67 Fiallo $P$, Nunzi E, Cardo PP. Beta2 glycoprotein-1-dependent anticardiolipin antibodies as risk factors for reactions in borderline leprosy patients. Int $J$ Lepr Other Mycobact Dis 1998;66:387-8. 
68 Loizou S, Cazabon JK, Walport MJ, Tait D, So AK. Similarities of specificity and cofactor dependence in serum antiphospholipid antibodies from patients with human parvovirus B19 infection and those with systemic lupus erythematosus. Arthritis Rheum 1997;40:103-8.

69 Oldstone MB. Molecular mimicry and immune-mediated diseases. FASEB J 1998;80:355-77.

70 Karlsen AE, Dyrberg T. Molecular mimicry between non-self, modified self and self in autoimmunity. Semin Immunol 1998;10:25-34.

71 Albert $\mathrm{L}$, Inman RD. Molecular mimicry and autoimmunity. N Engl J Med 1999;341:2068-74

72 Blank M, Krause I, Fridkin M, Keller N, Kopolovic J, Goldberg I, et al. Bacterial induction of autoantibodies to $\beta 2$-glycoprotein-1 accounts for the infectious etiology of antiphospholipid syndrome. J Clin Invest 2002; 109:797-804

73 Zhang I, Jaconsson K, Strom K, Londberg M, Frykberg KL. Staphylococcus aureus expresses a cell surface protein that binds both lgG and B2glycoprotein 1. Microbiology 1999;145:177-83.

74 Gharavi EE, Chaimovich H, Cucurull E, Celli CM, Tang H, Wilson WA, et al Induction of antiphospholipid antibodies by immunization with synthetic viral and bacterial peptides. Lupus 1999;8:449-55.

75 Gharavi AE, Pierangeli SS, Espinola RG, Liu X, Coden-Stanfield M, Harris EN. Antiphospholipid antibodies induced in mice by immunization with a cytomegalovirus-derived peptide cause thrombosis and activation of endothelial cells in vivo. Arthritis Rheum 2002;46:545-52.

76 Ordi-Ros J, Villarreal J, Monegal F, Sauleda S, Estaban I, Vilardell M. Anticardiolipin antibodies in patients with chronic hepatitis $C$ infection characterization in relation to antiphospholipid syndrome. Clin Diagn Lab Immunol 2000;7:241-4.

77 Dalekos GN, Kistis KG, Boumba DS, Voulgari P, Zervou EK, Drosos AA, et al. Increased incidence of anti-cardiolipin antibodies in patients with hepatitis $C$ is not associated with aetiopathogenic link to antiphospholipid syndrome. Eur J Gastroenterol Hepatol 2000;12:67-74.

78 Sthoeger ZM, Fogel M, Smirov A, Ergas D, Lurie Y, Bass DD, et al. Anticardiolipin autoantibodies in serum samples and cryoglobulins of patients with chronic hepatitis C infection. Ann Rheum Dis 2000;59:483-6.

79 Cacoub P, Renou C, Rosenthal E, Cohen P, Loury I, Loustaud-Ratti V, et al. Extrahepatic manifestations associated with hepatitis $C$ infection. A prospective multicentre study of 321 patients. Medicine (Baltimore) 2000;79:45-56.

80 Muñoz-Rodríguez FJ, Tàssies D, Font J, Reverter JC, Cervera R, SánchezTapias $J M$, et al. Prevalence of hepatitis $C$ virus infection in patients with antiphospholipid syndrome. J Hepatol 1999;30:770-3.

81 Giordano P, Galli M, Del Vecchio GC, Altomare M, Norbis F, Ruggeri L, et al. Lupus anticoagulant anticardiolipin antibodies and hepatitis $C$ infection in thalassaemia. Br J Haematol 1998;102:903-6.
82 Yamazaki $M$, Asakura H, Kawamura Y, Ohka T, Endo M, Matsuda T. Transient lupus anticoagulant induced by Epstein-Barr virus infection. Blood Coagul Fibrinolysis 1991;2:771-4.

83 Barcat D, Constans J, Seigneur M, Guerin V, Conn C. Thrombose veineuse profonde contemporaine d'une varicelle de l'adulte. Rev Med Interne 1998;27:563-7.

84 Faghiri Z, Wilson WA, Taheri P, Barton EN, Morgan OS, Gharavi AE. Antibodies to cardiolipin and beta-2 glycoprotein 1 in HTLV-1-associated myelopathy/tropical spastic paraparesis. Lupus 1999:8:210-14.

85 Bloom EJ, Abrams DI, Rodgers G. Lupus anticoagulant in the acquired immunodeficiency syndrome. JAMA 1986;258:491-3.

86 Asherson RA, Shoenfeld Y. Human immunodeficiency virus infection, antiphospholipid antibodies, and the antiphospholipid syndrome. J Rheumatol 2003:30:214-19.

87 Argov S, Shattner Y, Burstein R, Handzel ZT, Shoenfeld Y. Autoantibodies in male homosexuals and HIV infection. Immunol Lett 1991;30:31-6.

88 Coll J, Gutierrez-Cebollada J, Yazbeck H, Berges A, Rubies-Prat J. Anticardiolipin antibodies and acquired immunodeficiency syndrome: prognostic marker or association with HIV infection? Infection 1992;20:140-2.

89 Fiallo P, Travaglino C, Nunzi E, Cardo PP. Beta-2 glycoprotein dependence of anticardiolipin antibodies in multibacillary leprosy patients. Lepr Rev 1998:69:376-81.

90 Levy RA, Pierangeli SA, Espinola RG. Antiphospholipid beta-2 glycoprotein 1 dependency assay to determine antibody pathogenicity [abstract]. Arthritis Rheum 2000;43s: 1476

91 Espinosa G, Santos E, Cervera R, Piette JC, de la Red G, Gil V, et al. Adrenal involvement in the antiphospholipid syndrome: clinical and immunologic characteristics of 86 patients. Medicine (Baltimore) 2003;82:106-18.

92 Asherson RA. The catastrophic antiphospholipid syndrome. J Rheumatol 1992;19:508-12.

93 Asherson RA. The pathogenesis of the catastrophic antiphospholipid syndrome. J Clin Rheumatol 1999;4:249-52.

94 Uhtman I, Taher A, Khalil I, Bizriu AR, Gharavi AE. Catastrophic antiphospholipid syndrome associated with typhoid fever. Comment on the article by Hayem et al. Arthritis Rheum 2002;46:850.

95 Asherson RA, Cervera R, de Groot PG, Erkan D, Boffa MC, Piette JC, et al. Catastrophic antiphosphospholipid syndrome: international consensus statement on classification criteria and treatment guidelines. Lupus 2003;12:530-4.

96 Asherson RA, Shoenfeld Y. The role of infection in the pathogenesis of catastrophic antiphospholipid syndrome - molecular mimicry? J Rheumatol 2000;27:12-14.

97 Annane D, Sébille V, Charpentier C, Bollaert PE, Francois B, Korach JM, et al. Effect of treatment with low doses of hydrocortisone and fludrocortisone on mortality in patients with septic shock. JAMA 2002;288:862-71. 